Prosiding Seminar Nasional Pendidik dan Pengembang Pendidikan Indonesia dengan Tema "Peningkatan Profesionalisme Pendidik di era Revolusi Industri 4.0”. Pendopo Gubernur NTB 27 Oktober 2018. ISSN 2598-1978

\title{
PENERAPAN PEMBELAJARAN KIMIA BERBASIS LINGKUNGAN MELALUI MODEL PROJECT BASED LEARNING UNTUK MENINGKATKAN SIKAP PEDULI LINGKUNGAN MAHASISWA
}

\author{
Magfirah Perkasa $^{1}$; Nurfidianty Annafi ${ }^{2}$; Putri Ayu Mutmainnah ${ }^{3}$ \\ 1,2,3 Pendidikan Kimia STKIP Bima \\ e-mail: magfirahperkasa@gmail..com
}

\begin{abstract}
Abstrak: Kimia merupakan ilmu alam, mempelajari tentang sifat dan karakteristik zat-zat serta unsur yang hampir banyak ditemui di alam. Sebagian besar kerusakan di alam yang juga menjadi masalah global saat ini disebabkan oleh zat-zat dan limbah kimia dari pengelolaan yang tidak benar. Beberapa isu global yang disebabkan oleh zat dan limbah kimia, diantaranya: penumpukan sampah, global warming, acid rain, pelubangan ozon, dan masalah lainnya. Masalah tersebut butuh penyelesaian secara berkesinambungan karena tidak dapat diselesaikan secara instan. Pembelajaran menggunakan model project based learning diharapkan dapat menjadi wadah implementasi untuk menerapkan pembelajaran kimia berbasis lingkungan sehingga dapat meningkatkan sikap peduli lingkungan mahasiswa. Penelitian ini bertujuan untuk meningkatkan sikap peduli lingkungan mahasiswa melalui penerapan pembelajaran berbasis lingkungan dengan menggunakan model project based learning. Instrumen pengumpulan data meliputi lembar observasi dan lembar penilaian diri. Hasil penelitian menunjukkan bahwa penerapan pembelajaran kimia berbasis lingkungan melalui model project based learning dapat meningkatakan sikap peduli lingkungan mahasiswa.
\end{abstract}

\section{Kata Kunci: Project Based Learning, Pembelajaran Berbasis Lingkungan, Peduli Lingkungan}

\section{PENDAHULUAN}

Indonesia merupakan negara kepulauan yang memiliki keragaman sumber daya alam yang melimpah. Kehidupan abad 21 menuntut tersedianya SDM yang dapat memanfaatkan potensi alam tersebut secara bijak demi pembangunan berkelanjutan untuk Indonesia. Hal ini menjadi tantangan bagi para pengambil kebijakan, akademisi dan stakeholders untuk dapat membentuk generasi yangdapat menjawab tantangan global namun juga berwawasan lingkungan. Pendidikan sebagai salah satu bidang investasi untuk pembangunan SDM juga memiliki peran penting untuk dapat mencetak generasi yang dituntut pada kehidupan abad 21 bervisi lingkungan.

Pembelajaran berbasis lingkungan dinilai sebagai sebuah inovasi dan visi pendidikan sebagai salah satu upaya untuk menjaga lingkungan dan pengembangan berbasis kelanjutan karena dapat memberikan paradigm bagi generasi mendatang untuk dapat menjaga lingkungan dan mengelola potensi sumber daya alam dengan bijak. Pembelajaran berbasis lingkungan dapat menjadi wadah untuk mengintegrasikan nilai, pengetahuan, keterampilan dan kesadaran pada mahasiswa sehingga dapat berkontribusi untuk lingkunga dan sosial (WWF-Malaysia, 2008). Mahasiswa dituntut untuk terampil dan mampu memanfaatkan lingkungan sekitar sebagai sumber belajar sains untuk menunjang tercapainya tujuan intruksional pembelajaran yang telah ditetapkan dan menumbuhkan sikap peduli lingkungan. Melalui pemanfaatan sumber belajar dari lingkungan sekitar dan kehidupan sehari-hari, siswa dapat mengembangkan kreativitas dalam sains, keterampilan proses sains, kemampuan berpikir, bersikap ilmiah, dan mampu menyelesaikan masalah-masalah secara ilmiah (scientific literacy). Terdapat beberapa dimensi sains yang diharapkan mampu dikuasai oleh siswa, dimensi tersebut diantaranya: produk ilmiah berupa pengetahuan (scientific product), proses ilmiah (scientific process), sikap ilmiah (scientific attitude), aplikasinya dalam kehidupan sehari-hari (application) dan kreativitas (creativity).

Kimia merupakan salah satu ilmu alam, mempelajari tentang sifat dan karakteristik zat-zat serta unsur yang hampir banyak ditemui di alam. Sebagian besar kerusakan di alam yang juga menjadi masalah global saat ini disebabkan oleh zat-zat dan limbah kimia dari pengelolaan yang tidak benar. Beberapa isu global yang disebabkan oleh zat dan limbah kimia, diantaranya: 
penumpukan sampah, global warming, acid rain, pelubangan ozon, dan masalah lainnya. Masalah tersebut butuh penyelesaian secara berkesinambungan karena tidak dapat diselesaikan secara instan. Oleh karena itu, perlu adanya penanaman sikap peduli lingkungan sedini mungkin khususnya pada pendidikan dasar, menengah dan pendidikan tinggi.

Permasalahan tentang kurangnya kesadaran dan kepedulian terhadap lingkungan juga terjadi pada generasi di beberapa negara lainnya. Masalah tersebut dapat diminimalisir dengan pembelajaran kimia berbasis pendidikan lingkungan berkelanjutan. Sikap peduli lingkungan (environmental care) merupakan representasi pengetahuan, sikap dan keterampilan siswa melalui pembelajaran kimia untuk dapat menyelesaikan permasalahan lingkungan di sekitarnya. Seorang siswa dinyatakan memiliki kesadaran terhadap lingkungan apabila mampu mengimplementasikan konsep kimia yang telah diketahuinya untuk menyelesaikan permasalahan serta mencegah terjadinya kerusakan lingkungan. Sikap peduli lingkungan merupakan salah satu domain dalam literasi lingkungan (environmental literacy), selengkapnya disajikan pada Gambar 2. Terdapat lima komponen yang terdapat dalam literasi lingkungan, yaitu : pengetahuan (knowledge) kesadaran (awareness), perilaku (behavior), keterlibatan (involvement) dan sikap (attitude) (Perkasa \& Wiraningtyas , 2017; Perkasa \& Aznam, 2016; Jannah, et al., 2013; Saxena \& Srivastava, 2012).

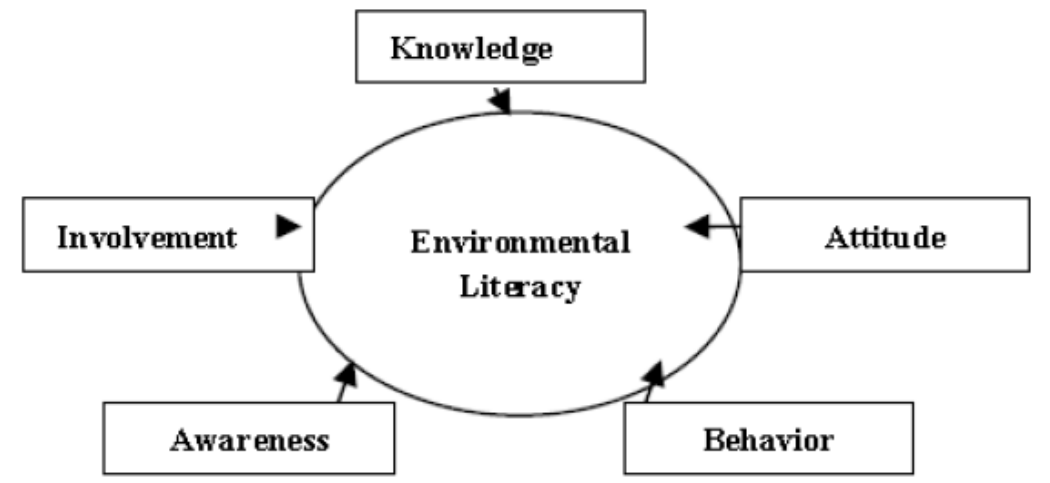

Gambar 1. Domain Literasi Lingkungan

Pembelajaran berbasis pendidikan lingkungan berkelanjutan telah dilakukan di beberapa negara dan menjadi landasan penerapan beberapa strategi belajar oleh United Nations Educational, Scientific, and Cultural Organization (UNESCO) untuk meningkatkan kesadaran dan kepedulian pembelajar terhadap lingkungan (environmental awareness) (UNESCO, 2002: 4). Organization for Economic Co-operation and Development (OECD) juga merekomendasikan bahwa sikap peduli lingkungan mahasiswa dapat ditingkatkan salah satunya dengan konsep pembelajaran berbasis pendidikan pendidikan berkelanjutan (OECD, 2013: 37). Beberapa strategi dan model pembelajaran untuk menyisipkan sikap peduli lingkungan meliputi: project based learning, story-telling, values education, inquiry learning, appropriate assessment, future problem-solving, learning outside the classroom, \& community problem solving (UNESCO, 2002: 5).

Pada penelitian ini, diterapkan model project based learning untuk dapat meningkatkan sikap peduli lingkungan mahasiswa. Model pembelajaran berbasis proyek merupakan model yang menstimulasi siswa untuk dapat melakukan suatu proses penelitian terhadap suatu permasalahan, diakhiri dengan adanya sebuah hasil proyek yang dikomunikasikan dan disajikan. Sintaks model pembelajaran berbasis proyek, yaitu : menganalisis masalah; membuat desain dan jadwal pelaksanaan proyek; melaksanakan penelitian; menyusun draft/prototype/produk; mengevaluasi produk dan finalisasi serta publikasi produk (Perkasa, 2017; Abidin, 2014). Oleh karena itu, untuk menyelesaikan beberapa masalah di atas, perlu adanya penerapan pembelajaran kimia berbasis lingkungan melalui model project based learning untuk meningkatkan sikap peduli lingkungan mahasiswa.

\section{METODE PENELITIAN}

Jenis penelitian ini merupakan penelitian tindakan kelas (classroom action research) dengan satu siklus. Desain penelitian menggunakan one group pretest-posttest. Instrumen pengumpulan data meliputi lembar observasi dan lembar penilaian diri.Subjek penelitian ini merupakan 
mahasiswa kelas A semester II Program Studi Pendidikan Kimia STKIP Bima sebanyak 10 orang yang diperoleh dengan menggunakan purposive sampling. Penelitian dilaksanakan pada semester genap tahun akademik 2017/2018. Prosedur penelitian mencakup tahap perencanaan, pelaksanaan, observasi dan refleksi. Prosedur penelitian ditunjukkan pada Gambar 2.

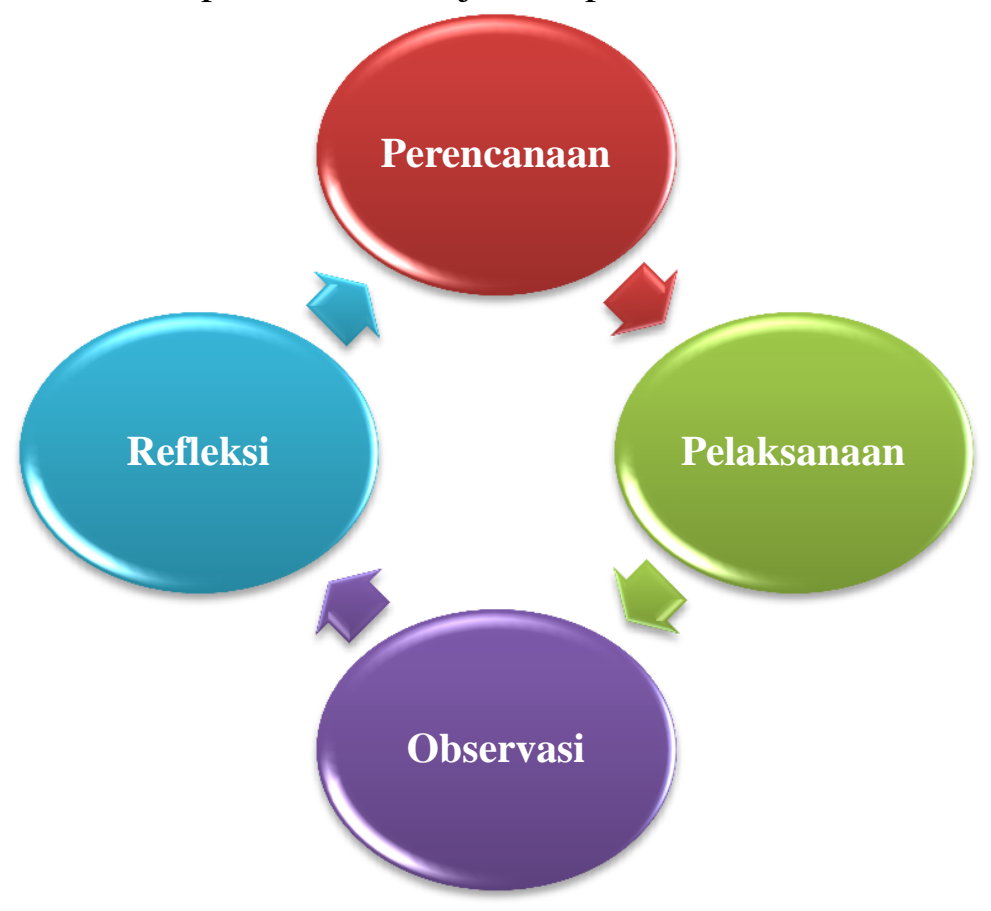

Gambar 2. Prosedur Penelitian

\section{HASIL DAN PEMBAHASAN \\ Deskripsi Data Penelitian}

Pada pengisian lembar penilaian diri awal, perolehan skor mahasiswa menunjukkan hasil yang beragam. Rata-rata skor perolehan mahasiswa pada awal yaitu 29,60 dengan skor tertinggi 34 dan skor terendah 26. Hal ini menunjukkan bahwa pada dasarnya sikap peduli lingkungan telah tertanam pada pribadi mahasiswa sebagai hasil interaksi mahasiswa dengan lingkungan sejak kecil. Penelitian ini memberikan alternatif sehingga sikap peduli lingkungan yang telah ada dalam diri mahasiswa ini agar dapat dioptimalkan dan diasah melalui penerapan pembelajaran kimia berbasis lingkungan melalui model project based learning. Hasil perolehan mahasiswa pada pengisian lembar penilaian diri akhir, setelah diberikan tindakan, menunjukkan hasil yang berbeda. Rata-rata skor perolehan mahasiswa pada awal yaitu 44,20 dengan skor tertinggi 40 dan skor terendah 48 . Data hasil penelitian diperoleh dengan mengukur sikap peduli lingkungan mahasiswa sebelum dan sesudah pemberian tindakan disajikan berikut.

Tabel 1. Skor Hasil Sikap Peduli Lingkungan Mahasiswa

$\begin{array}{cccccc}\text { No. } & \text { Kode Subjek } & \text { Skor Awal } & \text { Skor Akhir } & \text { Gain Skor } & \text { Kategori Gain Skor } \\ 1 . & 1 & 26 & 40 & 0.64 & \text { sedang } \\ 2 . & 2 & 34 & 45 & 0.79 & \text { tinggi } \\ 3 . & 3 & 32 & 44 & 0.75 & \text { tinggi } \\ 4 . & 4 & 28 & 46 & 0.90 & \text { tinggi } \\ 5 . & 5 & 27 & 42 & 0.71 & \text { tinggi } \\ 6 . & 6 & 30 & 43 & 0.72 & \text { tinggi } \\ 7 . & 7 & 29 & 48 & 1.00 & \text { tinggi } \\ 8 . & 8 & 31 & 47 & 0.94 & \text { tinggi } \\ 9 . & 9 & 32 & 41 & 0.56 & \text { sedang } \\ 10 . & 10 & 27 & 46 & 0.90 & \text { tinggi } \\ & \text { Skor Terendah } & \mathbf{2 6} & \mathbf{4 0} & \mathbf{0 . 5 6} & -\end{array}$


Prosiding Seminar Nasional Pendidik dan Pengembang Pendidikan Indonesia dengan Tema "Peningkatan Profesionalisme Pendidik di era Revolusi Industri 4.0”. Pendopo Gubernur NTB 27 Oktober 2018. ISSN 2598-1978

\section{Skor Tertinggi \\ Rata-rata}

\section{PEMBAHASAN}

34

29.60

\section{8}

44.20
1.00

0.79

Berdasarkan data yang disajikan pada Tabel 1 diperoleh informasi bahwa pada tahap awal pretest semua mahasiswa masih memperoleh nilai dibawah standar capaian (35). Perolehan gain skor sikap peduli lingkungan mahasiswa menunjukkan peningkatan dengan keragaman skor yang berbeda. Peningkatan sikap peduli lingkungan mahasiswa ditandai dengan $80 \%$ subjek yang telah berkategori gain skor tinggi yaitu lebih dari 0,7. Capaian skor rata-rata pada awal yaitu 29,60 dan akhir yaitu 44,20. Gain skor yang diperoleh mahasiswa merepresentasikan capaian sikap peduli lingkungan mahasiswa yang mengalami peningkatan.

Gain skor tertinggi mahasiswa yaitu 1,00 dimana perolehan skor awal sebesar 29 dan perolehan skor akhir 48. Gain skor terendah mahasiswa yaitu 0,56 dimana skor awal sebesar 32 dan perolehan skor akhir 41. Hasil analisis dan pengamatan selama proses pembelajaran, sikap peduli lingkungan siswa telah ada dan tertanam dalam pribadi mahasiswa, hanya sikap ini masih berkategori Functional Environmental Literacy. Hal ini bermakna bahwa sikap peduli lingkungan mahasiswa masih berupa sikap yang didasari atas pengetahuian tentang definisi, konsep sains secara ilmiah yang dipelajari, belum berlandaskan kesadaran yang utuh dan keterlibatan penuh secara menyeluruh. Analogi kategori ini dijelaskan seperti berikut: semua orang memahami bahwa sampah plastik tidak dapat diurai oleh mikroba tanah, sehingga harus dibuang pada tempat sampah sehingga dapat diolah secara berkelanjutan. Namun, pengetahuan ini tidak lahir dari kesadaran yang penuh, sehingga masih memungkinkan terjadinya pelanggaran dan membuat sampah plastik sembarang jika tidak dilihat oleh orang lain.

\section{KESIMPULAN}

\section{Simpulan}

Berdasarkan hasil penelitian dan pembahasan, dapat disimpulkan bahwa penerapan pembelajaran kimia berbasis lingkungan melalui model project based learning dapat meningkatkan sikap peduli lingkungan mahasiswa. Sikap peduli lingkungan mahasiswa berkategori Functional Environmental Literacy yang bermakna bahwa sikap peduli lingkungan mahasiswa masih berupa sikap yang didasari atas pengetahuian tentang definisi, konsep sains secara ilmiah yang dipelajari, belum berlandaskan kesadaran yang utuh dan keterlibatan penuh secara menyeluruh.

\section{Ucapan Terima Kasih}

Ucapan terima kasih dan apresiasi tertinggi penulis sampaikan kepada Direktorat Riset dan Pengabdian Masyarakat, Kemenritekdikti yang telah membantu mendanai penelitian ini melalui hibah dosen pemula (PDP).

\section{DAFTAR RUJUKAN}

Abidin , Y. (2014). Desain Sistem Pembelajaran Dalam Konteks Kurikulum 2013. Bandung: Refika Aditama.

Jannah, M., Halim, L., \& Meerah, S. M. (2013). Impact of Environmental Education Kit on Students' Environmental Literacy. Asian Social Science, 9(12), 1-12.

OECD. (2013). PISA 2015: Draft Science Framework. New York: OECD Printing Office.

Perkasa, M., \& Aznam, N. (2016). Pengembangan SSP Kimia Berbasis Pendidikan Berkelanjutan untuk Meningkatkan Literasi Kimia dan Kesadaran Terhadap Lingkungan. Jurnal Inovasi Pendidikan IPA, 2(1), 46-57.

Perkasa, M., \& Wiraningtyas , A. (2017). Pembelajaran Kimia Berorientasi Sustainable Development untuk Meningkatkan Kesadaran Siswa Terhadap Lingkungan. Jurnal Sainsmat, VI(2), 63-72.

Saxena, P., \& Srivastava, P. (2012). Environmental Awareness of Senior Secondary Students in Relation to Their Eco-Friendly Behaviour. Research Scapes, I(II), 1-8.

UNESCO. (2002). Teaching and Learning for A Sustainable Future. Australia: Griffith University Publisher. 
Prosiding Seminar Nasional Pendidik dan Pengembang Pendidikan Indonesia dengan Tema "Peningkatan Profesionalisme Pendidik di era Revolusi Industri 4.0”. Pendopo Gubernur NTB 27 Oktober 2018. ISSN 2598-1978

WWF-Malaysia. (2008). Strengthening Environmental Education in existing National Curriculum. Malaysia: WWF-Malaysia. 